\title{
Anxiolytic and Antidepressant Potentials of Ethanol Extract of Artocarpusaltilis (Breadfruit) in Laboratory Rodent
}

\begin{abstract}
Ajah AA*, Amah-Tariah FS and Iwu I
Department of Human Physiology, Faculty of Basic

Medical Sciences, University of Port Harcourt, Nigeria

*Corresponding author: Ajah AA, Faculty of Basic Medical Sciences, College of Health Sciences, University of Port-Harcourt Rivers State, Nigeria
\end{abstract}

Received: March 08, 2018; Accepted: April 20, 2018; Published: April 27, 2018

\begin{abstract}
This study evaluates the Anxiolytic and Ant-depressant potentials of Artocarpusaltilis (Breadfruit) in Laboratory Rodents. A total of $30 \mathrm{~W}$ istaralbino mice weighing $25-30 \mathrm{~g}$ categorized into five groups of six mice each were used for the study. EPM \& LD Box tests and TST \& FST were carried out in the Anxiolytic and anti-depressant studies respectively. Group I served as the control group and were administered 1mil of normal saline orally in both studies. Group II; negative control were administered $1 \mathrm{mg} / \mathrm{kg}$ Diazepam and $20 \mathrm{mg} / \mathrm{kg}$ of Imipramine orally for Anxiolytic and Anti-depressant studies respectively. Group III, IV and V were administered EEAA in doses of $50 \mathrm{mg} / \mathrm{kg}, 100 \mathrm{mg} / \mathrm{kg}$ and $200 \mathrm{mg} / \mathrm{kg}$ orally respectively in both studies. Anxiety related behaviors such as duration of time spent in the open arm and number of entries into the open arm for EPM, duration of time spent in the light chamber and number of entries into the light chamber L/D Box were observed for (5mins). Depression-like behaviors such as duration of time spent immobile and climbing were observed for 6 mins with acclimatization time of $2 \mathrm{mins}$ out of the $6 \mathrm{~min}$ in both TST and FST The test groups were compared with the control group in both studies. The result showed that oral administration of EEAA caused significant $(p<0.05)$ anxiolytic and antidepressant effects in mice. Hence ethanol extract of Artocarpusaltilis possesses significant anxiolytic and anti-depressant effect in mice.
\end{abstract}

Keywords: Artocarpusaltilis; Anxiolytic and Anti-depressant effect; EEAA (Ethanol Extract of Artocarpusaltilis; EPM (Elevated Plus Maze); L/D Box (Light and Dark Transition Box); TST (Tail Suspension Test); FST (False Swim Test)

\section{Introduction}

Anxiety is an emotion characterized by an unpleasant state of inner turmoil, often accompanied by nervous behavior, such as pacing back and forth, somatic complaints, and rumination [1]. It is the subjectively unpleasant feelings of dread over anticipated events, such as the feeling of imminent death. Anxiety is not the same as fear, which is a response to a real or perceived immediate threat, whereas anxiety is the expectation of future threat [2]. Anxiety is a feeling of fear, uneasiness, and worry, usually generalized and unfocused as an overreaction to a situation that is only subjectively seen as menacing [3]. It is often accompanied by muscular tension, restlessness, fatigue and problems in concentration. Anxiety can be appropriate, but when experienced regularly the individual may suffer from an anxiety disorder [4].

People facing anxiety may withdraw from situations which have provoked anxiety in the past. There are various types of anxiety. Existential anxiety can occur when a person faces angst, an existential crisis, or nihilistic feelings. People can also face mathematical anxiety, somatic anxiety, stage fright, or test anxiety [5]. Social anxiety and stranger anxiety are caused when people are apprehensive around strangers or other people in general. Furthermore, anxiety has been linked with physical symptoms such as Irritable Bowel Syndrome (IBS) and can heighten other mental health illnesses such as Obsessive
Compulsive Disorder (OCD) and panic disorder [6]. Whereas trait anxiety represents worrying about future events, close to the concept of neuroticism, anxiety disorders are a group of mental disorders characterized by feelings of anxiety and fear [7]. Anxiety disorders are partly genetic but may also be due to drug use, including alcohol, caffeine, and benzodiazepines (which are often prescribed to treat anxiety), as well as withdrawal from drugs of abuse [8].

Depression is a state of low mood and aversion to activity that can affect a person's thoughts, behavior, feelings and sense of wellbeing [9]. People with a depressed mood can feel sad, anxious, empty, hopeless, helpless, worthless, guilty, irritable, angry, ashamed or restless. They may lose interest in activities that were once pleasurable, experience loss of appetite or overeating, have problems concentrating, remembering details or making decisions, experience relationship difficulties and may contemplate, attempt or commit suicide. Insomnia, excessive sleeping, fatigue, aches, pains, digestive problems or reduced energy may also be present [10].

It is often said that depression results from a chemical imbalance, but that figure of speech doesn't capture how complex the disease is. Research suggests that depression doesn't spring from simply having too much or too little of certain brain chemicals. Rather, depression has many possible causes, including faulty mood regulation by the brain, genetic vulnerability, stressful life events, medications, and 


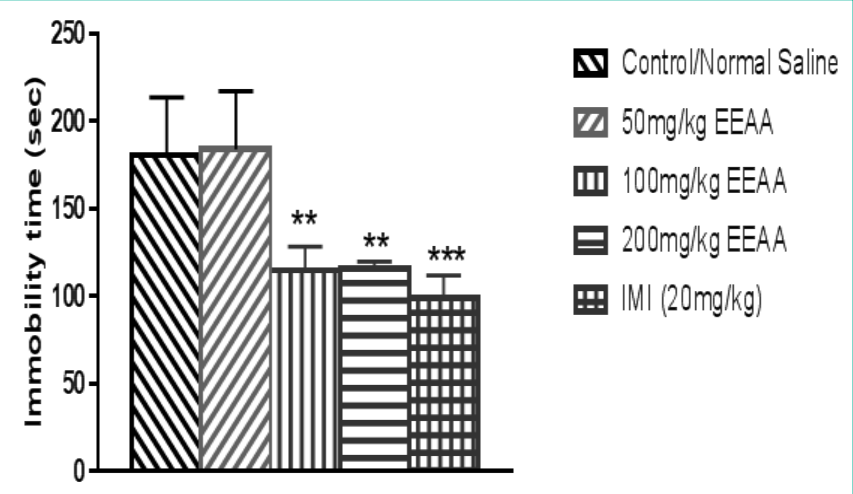

Figure 1: Behavioral potentials of Ethanol extract of Artocarpusaltilis and Imipramine on depression status of mice in tail suspension test. Statistically significant at ${ }^{* *}: p<0.01,{ }^{* * *}: p<0.001$ Compared to control.

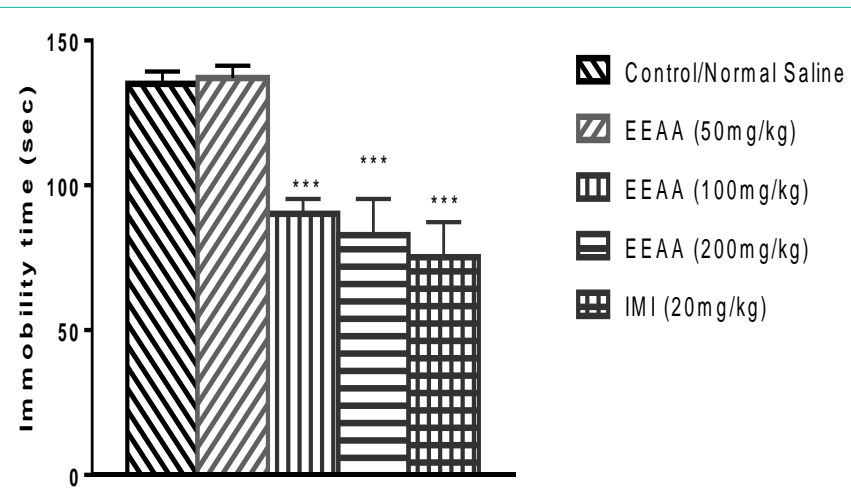

Figure 2: Behavioral potentials of Ethanol extract of Artocarpusaltilis and Imipramine on depression status of mice in forced swimming test. Statistically Significant at ${ }^{* *}: p<0.001$ Compared to control.

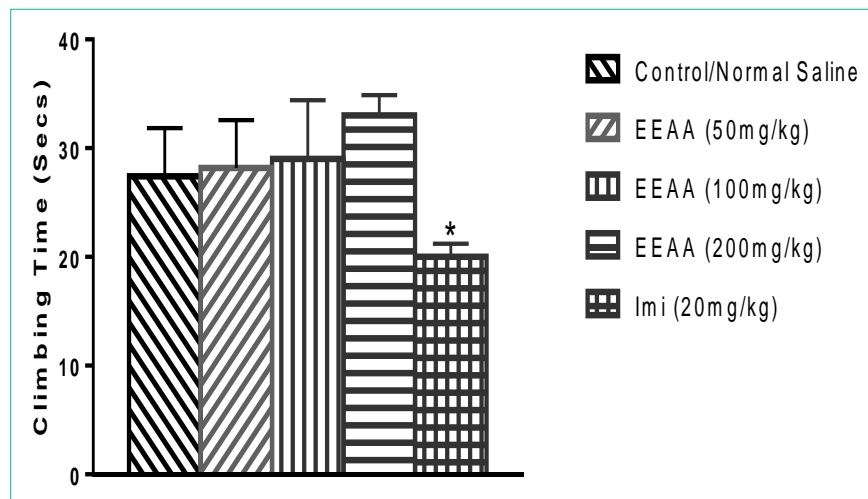

Figure 3: Behavioral potentials of Ethanol extract of Artocarpusaltilis and imipramine on depression status of mice in forced swimming test. Statistically significant at ${ }^{*} p<0.05$ Compared to control.

medical problems. It's believed that several of these forces interact to bring on depression [11]. With this level of complexity, you can see how two people might have similar symptoms of depression, but the problem on the inside, and therefore what treatments will work best, may be entirely different [12]. And while researchers know more now than ever before about how the brain regulates mood, their understanding of the biology of depression is far from complete [13].

Breadfruit is a common name for fruits belonging to the genera Artocarpus [14] although it usually refers to Artocarpusaltilis $[15,16]$.
Research on the efficacy of breadfruit extracts from various parts of the plants has shown promising results. Artocarpus extracts and metabolites from leaves stem, fruit and bark contain numerous beneficial biologically active compounds and these compounds are used in the various biological activities including antibacterial, antitubercular, antiviral, antifungal, antiplatelet, antiarthritic, tyrosinase inhibitory and cytotoxicity [17].

Previous research on the chemical constituents of Artocarpusaltilis has resulted in the isolation of several classes of compounds such as flavonoids [18] and triterpenoids [19]. A previous study indicated that some flavonoids from Artocarpusaltilis could inhibit 5-lipoxygenas of cultured mastocytoma cells [20]. The aqueous leaf extract Artocarpusaltilis proved has an antihypertensive as it produces negative chronotropic and hypotensive effects through $\alpha$-adrenoceptor and $\mathrm{Ca}^{2+}$ channel antagonism [21]. In our area, due to the availability and accessibility to plant products and herbs, the alternative therapies to orthodox treatments are always these plant products and herbs $[14,22]$. The present study tends to investigate the anxiolytic and anti-depressant potentials of ethanol extract of Artocarpusaltilis (breadfruit).

\section{Materials and Methodology}

The study was carried out in the Department of Human Physiology, Faculty of Basic Medical Sciences, College of Health Sciences in the University of Port Harcourt, Nigeria.

\section{Drugs}

Diazepam and Imipramine were obtained from a local pharmacy duly registered by the Pharmacists` Council of Nigeria (PCN).

\section{Plant materials}

Artocarpusaltilis (breadfruit) were purchased from Port-Harcourt Central Fruit market. The fruits were identified and confirmed for use by a botanist in the University of Port Harcourt herbarium. The fruits were then ground into powder form. The powdered Artocarpusaltilis was soaked with $100 \%$ ethanol in a glass jar container and was left for a period of 72 hours. Thereafter, the mixture was decanted using filter paper and then evaporated using rotator evaporator. The extract was evaporated to semi-solid form [23] and then preserved in a refrigerator, from which appropriate quantity was collected to formulate the various administered doses [24].

\section{Animals}

Thirty (30) male Wistar strain albino mice weighting 25-30g were used for the study, under the approval of the ethics committee on care and handling of experimental animals in the University of Port Harcourt. The albino mice were supplied from the animal house of the department of Human Physiology, University of Port Harcourt. The animals were housed under standard conditions of temperature $\left(23 \pm 2^{\circ} \mathrm{C}\right)$, humidity $(55 \pm 15 \%)$ and $12 \mathrm{~h}$ light $(7.00 \mathrm{am}-7.00 \mathrm{pm})$. The animals were put into a wire meshed wooden and were allowed to acclimatize for 14 days while fed with normal commercial rodent chew and allowed water ad libitum. After acclimatization, they were randomly grouped into five groups of six animals each.

\section{Treatment}

Group I which served as the control group (negative control) was given $10 \mathrm{ml} / \mathrm{kg}$ of distilled water orally. Group II served as the 


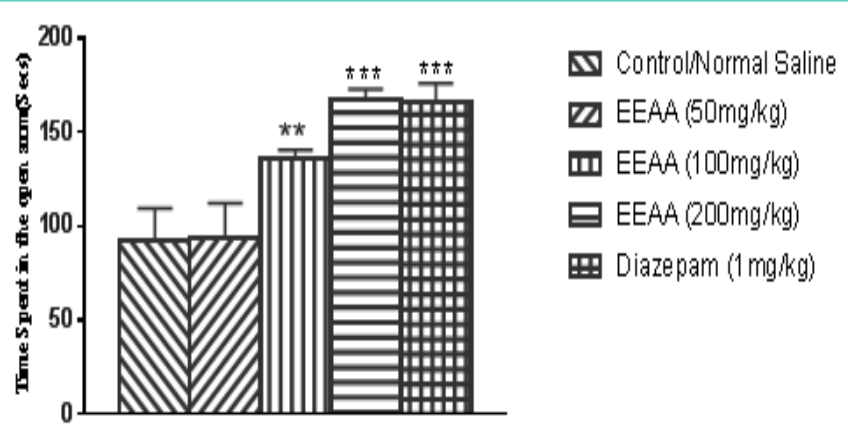

Figure 4: Behavioral potentials of Ethanol extract of Artocarpusaltilis and Diazepam on anxiety status of mice in elevated-plus maze test. Statistically significant at ${ }^{* *}: p<0.01,{ }^{* * *}: p<0.001$ Compared to control.

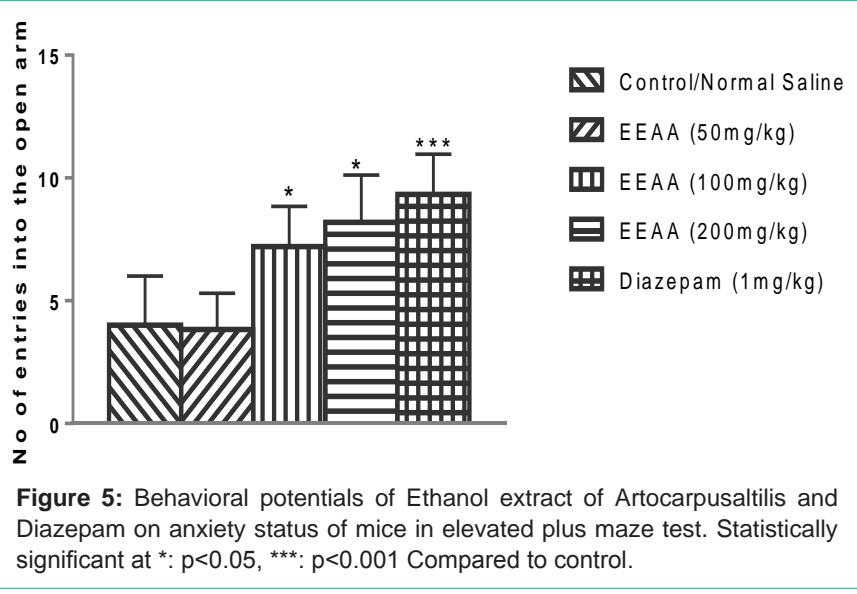

negative control and was administered $1 \mathrm{mg} / \mathrm{kg}$ Diazepam and 20mg/ $\mathrm{kg}$ of Imipramine orally for Anxiolytic and Anti-depressant studies respectively, Groups III, IV and V received 50, 100, and 200mg/kg of ethanol extract of Artocarpusaltilis orally respectively.

\section{Experimental procedure for depression}

The Tail suspension test [25] and Forced swimming test of [26,27] were used for depression study.

The Tail Suspension Test is an experimental method used in scientific research to measure stress in rodents. It is used to measure the effectiveness of anti-depressant like agents [25]. While forced swimming test also known as behavioral despair test or Porsolt forced swimming test is most commonly used animal models for assessing antidepressant-like behavior [26-28]. They are based on the observation that if a rat if subjected to short term inescapable stress then the rat will become immobile. The duration of immobility can only be decrease by an anti-depressant drugs [29,30].

\section{Experimental procedure for anxiety}

Elevated-Plus Maze (EPM), and Light-Dark (LD) test were carried out in this study to examine anxiety-like behavior in rodents $[31,32]$. The elevated plus maze is a test that measures anxiety in laboratory animals such as mice. The model is based on the test animal's aversion to open tendency to be thigmotaxic. In the elevated plus maze, this anxiety is expressed by the animal spending more time in the enclosed arms. Light and dark box transition test measures anxiety related behaviors in rodent animals. The test is based on the

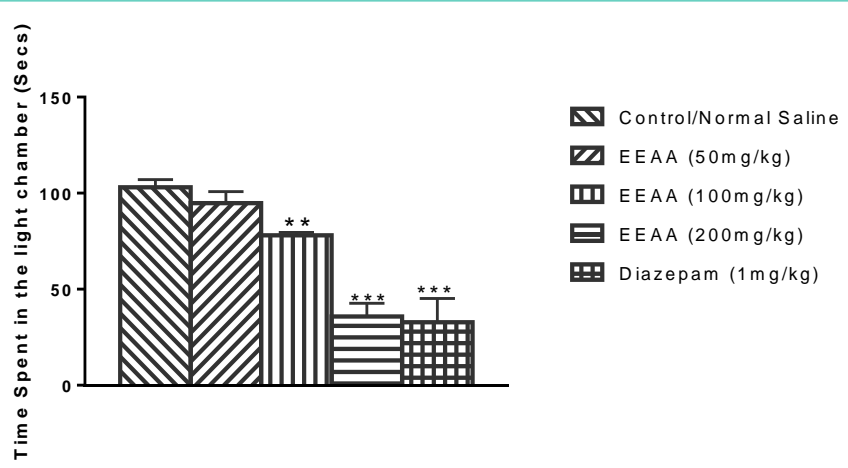

Figure 6: Behavioral potentials of Ethanol extract of Artocarpusaltilis and diazepam on anxiety status of mice in light and dark test. Statistically significant at ${ }^{* *}: p<0.01,{ }^{* * *}: p<0.001$ Compared to control.

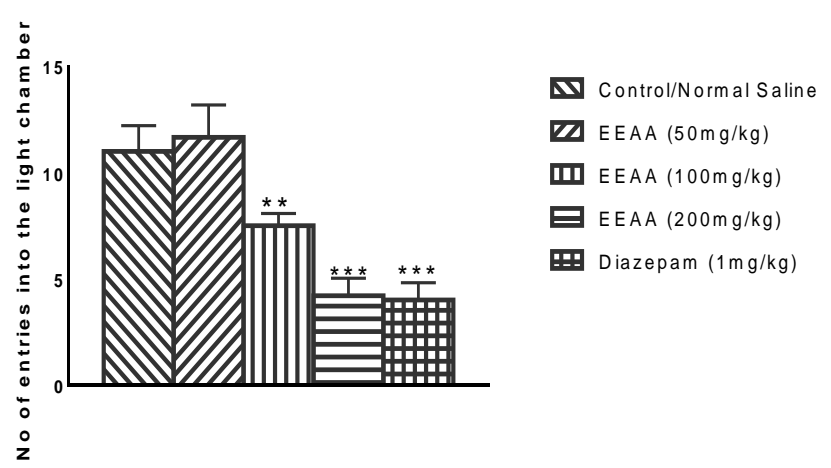

Figure 7: Behavioral potentials of Ethanol extract of Artocarpusaltilis and Diazepam on anxiety status of mice in light and dark test. Statistically significant at ${ }^{* *}: p<0.01,{ }^{* * *}: p<0.001$ Compared to control.

natural aversion of mice to brightly illuminated areas and on their spontaneous exploratory behavior in novel environments [33].

\section{Statistical analysis}

The values are expressed as mean \pm SEM. Hypothesis testing method included one way analysis of variance (ANOVA) followed by post hoc performed with Least Significant Difference (LSD) Dunnett. $\mathrm{P}$ value of less than 0.005 was considered to indicate statistical significance and 0.001 as highly significant respectively.

\section{Results}

This is expressed in the Tables and figure section after references.

\section{Discussion}

Anxiety disorders are partly genetic but may also be triggered, due to drug use, including alcohol and caffeine, as well as withdrawal from certain drugs. They often occur with other mental disorders, particularly major depressive disorder, bipolar disorder, certain personality disorders, and eating disorders. The term anxiety covers four aspects of experiences that an individual may have: mental apprehension, physical tension, physical symptoms and dissociative anxiety [34]. The emotions present in anxiety disorders range from simple nervousness to bouts of terror [35]. Depression can be seen as a state of low mood and aversion to activity that can affect a person's thoughts, behavior, feelings and sense of well-being [9].

Results obtained from behavioral models of depression tail 
suspension test and false swimming test, Figurel shows a significant decrease $(\mathrm{p}<0.01$ and $\mathrm{p}<0.001)$ in immobility time in group that was administered $(100 \mathrm{mg} / \mathrm{kg}$ and $200 \mathrm{mg} / \mathrm{kg})$ of the extract and imipramine when compared to the control group. Decrease in the duration of immobility indicates some degree of significance in the anti-depressant ability of the extract and drug [30].

Figure 2 shows a significant difference $(\mathrm{p}<0.001)$ in immobility time in group that was administered $(100 \mathrm{mg} / \mathrm{kg}$ and $200 \mathrm{mg} / \mathrm{kg}$ ) of the extract and imipramine when compared to the control group. As stated $[26,27]$ that mice after 2 min of vigorous struggle, adopted a typical posture of immobility (floating in the water making only the slight movements necessary to keep the head above the water), alternated with swimming or paddling movement. This stressinduced failure in escape performance was named "behavioral despair" and has been consistently prevented by the treatment of rats or mice with different types of antidepressants [26,27]. In contrast to the forced swim test, in the TST there is no risk of hypothermia due to submersion in water, the stressful situation hemodynamic stress of being hung in an uncontrollable fashion by their tail. This result suggests that the EEAA possess Anti-depressant like effect in mice.

Anxiety is evaluates using Elevated-Plus Maze (EPM), and LightDark (LD) test were carried out in this study to examine anxiety-like behavior in rodents. In EPM, the behavioral model is based on the general aversion of rodents to open spaces. This aversion leads to the behavior termed thigmotaxis in Figure 3, a preference for remaining in enclosed spaces or close to the edges of a bounded space. In the EPM, this translates into the animals limiting their movement to the enclosed arms [30,32]. Anxiety reduction is indicated in the plusmaze by an increase in the proportion of time spent in the open arms and an increase in the proportion of entries into the open arms. The total number of arm entries and number of closed-arm entries are sometimes used as measures of general activity [32].

Figures 4 and 5 shows a significant increase $(\mathrm{p}<0.01$ and $\mathrm{p}<0.001)$ in time spent in the open arm and number of entries into the open arm in group that was administered $(100 \mathrm{mg} / \mathrm{kg}$ and $200 \mathrm{mg} / \mathrm{kg}$ ) of the extract and imipramine when compared to the control group. The administration of anxiolytic drugs decreases anxiety by increasing the proportion of time spent in the open arms and an increase in the proportion of entries into the open arms [36].

The light/dark transition test is one of the most widely used tests to measure anxiety-like behavior in mice. The test is based on the natural aversion of mice to brightly illuminated areas and on their spontaneous exploratory behavior in novel environments. The test is sensitive to anxiolytic drug treatment [33]. The light/dark test is based on the innate aversion of rodents to brightly illuminated areas and on the spontaneous exploratory behavior of rodents in response to mild stressors, that is, novel environment and light [33]. Figures 6 and 7 shows a significant difference $(\mathrm{p}<0.01$ and $\mathrm{p}<0.001)$ in time spent in the light chamber and number of entries into the light chamber in group that was administered $(100 \mathrm{mg} / \mathrm{kg}$ and $200 \mathrm{mg} / \mathrm{kg})$ of the extract and imipramine when compared to the control group. The administration of anxiolytic drugs decreases anxiety by increasing the proportion of time spent in the light chamber and an increase in the proportion of entries into the light chamber [33].

\section{Conclusion}

In conclusion, the results obtained from this study indicate that EEAA, similar to imipramine and diazepam has anti-depressant and anxiolytic effects in the acute depression and anxiety models status in mice respectively. The result gotten from this study shows that effect of EEAA on anxiety and depression is dose dependent.

\section{Recommendations}

Further Studies needs to be carried out to establish the mechanism through which the ethanol extract of Artocarpusaltilis carries out its anxiolytic and anti-depressant effect.

\section{References}

1. Seligman MEP, Walker EF, Rosenhan DL. Abnormal psychology ( $4^{\text {th }}$ edn). New York: WW Norton \& Company. 2007.

2. Davison, Gerald C. Abnormal Psychology. Toronto: Veronica Visentin. 2008: 154.

3. American Psychiatric Association. Diagnostic and Statistical Manual of Mental Disorders ( $5^{\text {th }}$ edn). Arlington, VA: American Psychiatric Publishing. 2013: 189.

4. Bouras N, Holt G. Psychiatric and Behavioral Disorders in Intellectual and Developmental Disabilities ( $2^{\text {nd }}$ edn). Cambridge University Press. 2007.

5. Barker P. Psychiatric and Mental Health Nursing: The Craft of Caring. London: Edward Arnold. 2003.

6. Ormel J, Jeronimus BF, Kotov R, Riese H, Bos EH, Hankin B, et al. Neuroticism and common mental disorders: Meaning and utility of a complex relationship. Clinical Psychology Review. 2013; 33: 686-697.

7. Öhman Arne. Fear and anxiety: Evolutionary, cognitive, and clinical perspectives. In Lewis, Michael; Haviland-Jones, Jeannette M. Handbook of emotions. New York: The Guilford Press. 2000: 573-593.

8. Barlow DH. Unraveling the mysteries of anxiety and its disorders from the perspective of emotion theory. Am Psychol. 2000; 55: 1247-1263.

9. Salmans Sandra. Depression: Questions You Have - Answers you need. People's Medical Society. 1997.

10. American Psychiatric Association. Diagnostic and Statistical Manual of Mental Disorders. Arlington: $5^{\text {th }}$ edn. 2013. 189-195

11. Szafran K, Faron-Górecka A, Kolasa M, Kuśmider M, Solich J, Zurawek, D, et al. Potential role of $\mathrm{G}$ protein-coupled receptor (GPCR) heterodimerization in neuropsychiatric disorders: a focus on depression. Pharmacol Rep. 2013. 65: 1498-1505

12. Naumenko VS, Popova NK, Lacivita E, Leopoldo M, Ponimaskin EG. Interplay between serotonin 5-HT1A and 5- $\mathrm{HT} 7$ receptors in depressive disorders. CNS Neurosci Ther. 2014; 20: 582-590.

13. Di Chiara G, Loddo P, Tanda G. Reciprocal changes in prefrontal and limbic dopamine responsiveness to aversive and rewarding stimuli after chronic mild stress: implications for the psychobiology of depression. Biol. Psychiatry. 1999; 46: 1624-1633.

14. Morton JF. Breadfruit. Fruits of Warm Climates (Miami, Florida): 50-58. Archived from the original on 5 January 2015. 1987

15. Ragone D. Breadfruit: Diversity, conservation and potential. In proceedings of the $1^{\text {st }}$ International Symposium on Breadfruit Research Development. Acta Horticulture. 2007; 757: 19-30.

16. Bailey LH. The standard Encyclopedia of Horticulture. The Mac-millan co. New York. 1942: 401-402.

17. Jagtap UB, Bapat VA. Artocarpus: A review of its traditional uses, phytochemistry and pharmacology. J Ethnopharmacol. 2010; 129: 142-166.

18. Lin CN, WL Shieh, TT Jong. A pyranodihydrobenzoxanthone epoxide from artocarpuscommuni. Phytochemistry. 1992; 31: 2563-2564. 
19. Altman LJ, SW Zito. Sterols and triterpenes from the fruit of Artocarpusaltilis. Phytochemistry. 1976; 15: 829-830.

20. Koshihara $\mathrm{Y}$, Fujimoto $\mathrm{Y}$, Inoue H. A new 5-lipoxygenase selective inhibitor derived from Artocarpuscommunis strongly inhibits arachidonic acid-induced ear edema. Biochem. Pharmacol. 1988; 37: 2161-2165

21. Nwokocha CR, Owu DU, McLaren M, Murray J, Delgoda R, Thaxter K, et al Possible mechanisms of action of the aqueous extract of Artocarpusaltilis (breadfruit) leaves in producing hypotension in normotensive SpragueDawley rats. Pharm Biol. 2012; 50: 1096-1102.

22. Igwe CU, Ojiako AO, Nwaogu LA, Onyeze GOC. Lipid lowering Effects of Aqueous Leaf Extract of Spondias mombin Linn. The Internet Journal of Pharmacology. 2008; 6: 1-9.

23. Hossain MA, Al-Hadrami SS, Weli AM, Al-Riyami Q, Al-Sabahi JN. Isolation, fractionation and identification of chemical constituents from the leave crude extract of Menthapiperita L grown in Suttanate of Oman. Asian Pac J Trop Biomed. 2014; 4: S368-S372.

24. DeGrazia D, Rowan A. Pain, suffering and anxiety in animals and humans Theor Med. 1991. 12: 193-211.

25. Steru L, Chermat R, Thierry B, Simon P. The tail suspension test: a new method for screening antidepressants in mice. Psychopharmacology (Berl). 1985; 85: 367-370

26. Porsolt RD, Bertin A, Jalfre $M$. Behavioural despair in mice: a primary screening test for antidepressants. Arch. Int. Pharmacodyn. Ther. 1977; 229: 327-336

27. Porsolt RD, Anton G, Blavet N, Jalfre M. Behavioural despair in rats: a new model sensitive to antidepressant treatments. Eur. J. Pharmacol. 1978; 47: 379-391.
28. Petit-Demouliere B, Chenu F, Bourin M. Forced swimming test in mice: a review of antidepressant activity. Psychopharmacology. 2005; 177: 245-255.

29. Cryan JF, Valentino RJ, Lucki I. Assessing substrates underlying the behavioral effects of antidepressants using the modified rat forced swimming test. Neurosci Biobehav Rev. 2005; 29: 547-569.

30. Cryan J, Page M, Lucki I. Differential behavioral effects of the antidepressants reboxetine, fluoxetine, and moclobemide in a modified forced swim test following chronic treatment. Psychopharmacology. 2005; 182: 335-344.

31. Ojo J, Mouzon B. Chronic Repetitive Mild Traumatic Brain Injury Results in Reduced Cerebral Blood Flow, Axonal Injury, Gliosis, and Increased T-Tau and Tau Oligomers. J Neuropathol Exp Neurol. 2016; 75: 636-655.

32. Hogg S. Review of the validity and variability of the elevated plus-maze as an animal model of anxiety. Pharmacol Biochem Behav. 1996; 54: 21-30.

33. Crowley JJ, Jones MD, O'Leary OF, Lucki I. Automated tests for measuring the effects of antidepressants in mice. Pharmacol Biochem Behav. 2004; 78 : 269-274

34. David Healy. Drugs Explained, Section 5: Management of Anxiety, Elsevier Health Sciences. 2008: 136-137

35. Phil Barker. Psychiatric and mental health nursing: the craft of caring London: Arnold. 2003.

36. Carobrez AP, Bertoglio LJ. Ethological and temporal analyses of anxiety-like behaviour: the elevated plus-maze model 20 years on. Neurosci Biobehav Rev. 2005; 29: 1193-1205.
Ann Depress Anxiety - Volume 5 Issue 1 - 2018

ISSN : 2381-8883 | www.austinpublishing group.com

Ajah et al. @ All rights are reserved
Citation: Ajah AA, Amah-Tariah FS and Iwu I. Anxiolytic and Antidepressant Potentials of Ethanol Extract of Artocarpusaltilis (Breadfruit) in Laboratory Rodent. Ann Depress Anxiety. 2018; 5(1): 1090. 